\title{
Internet-Mediated Dialog with Consumers: A Cross-Industry Multiple-Case Study of Polish Exporters
}

\author{
Piotr Zaborek ${ }^{1}$, Jolanta Mazur ${ }^{2}$
}

Submitted: 28.10.18. Final acceptance: 3.02 .19

\section{Abstract}

Purpose: The paper explores the online dialog of firms and consumers through corporate websites and social networks. The objective is to investigate the state of this dialog, its mechanisms, and outcomes in four export-oriented manufacturing companies that represent a wide spectrum of industries, including FMCG and durable goods, low-priced and expensive products, purchased with high and low involvement.

Methodology: A multiple-case study was used as the research method, with data sourced from in-depth interviews, observations, and published documents.

Findings: The findings show all managers agree that dialog with consumers is useful, they allocate resources to support it, but its intensity is underwhelming. Dialog effects were reported as positive but only as anecdotal evidence without validation in reliable data, which underscores measuring difficulties. It seems that dialog is the easiest to implement in and brings the most substantial benefits for high-involvement products but, even there, the feedback from consumers is not effectively used for developing product innovations. The major obstacle that restricts rich dialog is not technology but the intensity, speed, and quality of personal contact between employees and consumers.

Originality: The empirical material presented here offers original insights that foster a better understanding of online dialog between consumers and manufacturing companies. Our study contributes to the stream of research on value co-creation.

Keywords: dialog, interaction, the Internet, consumers, manufacturers, exporters, multiple-case study, value co-creation

JEL: M10, M14

\footnotetext{
1 Corresponding author: Warsaw School of Economics, Collegium of the World Economy, Institute of International Management and Marketing Correspondence address: Warsaw School of Economics, Collegium of the World Economy, Institute of International Management and Marketing, 6/8 Madalińskiego St., 02-513, Warsaw, email: piotr.zaborek@sgh.waw.pl, https://orcid.org/0000-0001-8809-5371

2 Warsaw School of Economics, Collegium of the World Economy, Institute of International Management and Marketing Correspondence address: Warsaw School of Economics, Collegium of the World Economy, Institute of International Management and Marketing, 6/8 Madalińskiego St., 02-513, Warsaw; email: jolanta.mazur@sgh.waw.pl
} 


\section{Introduction}

The current study explores the role of dialog in internationalized manufacturing companies as a means of communication with consumers.

Dialog is a process of two-way communication that involves common reasoning, shared meaning development, and building a common knowledge platform (Grönroos, 2000). Scholars long considered the concept of dialog to be the capstone of a successful customer relationship. With the rapid growth of the new marketing channel of the Internet and social media, dialog came to the forefront of marketing discourse. Indeed, the rise of social media prompted the development of the highly influential concepts of value co-creation (Prahalad and Ramaswamy, 2004) and service-dominant logic (Vargo and Lush, 2004), both of which foreground dialog with customers as their pivotal component.

Regardless of the recent strong interest in dialog that prompts quantitative and qualitative investigation along with conceptual works, there remains the need to thoroughly explore the matter in case-study research. One argument in favor of qualitative research is the fact that survey studies on dialog often rely on measurement scales with questionable construct validity. For a detailed discussion of challenges in measuring dialog and other aspects of value co-creation through survey questionnaires, see Ranjan and Read (2016) and Mazur and Zaborek (2016). What is partly responsible for this difficulty is the innate complexity of dialogic relationships that reflects the specificity of firms and markets, thus defying straightforward standardization. The original empirical material in this paper offers new insights into the process of online dialog, which could inspire changes in conceptual frameworks and measurement instruments of quantitative studies.

The purpose of this study is to thoroughly explore in a multiple-case study the application and outcomes of online dialog in four companies from different industries. We aim to identify inter-company discrepancies that could be ascribed to the specific nature of their operations, and the similarities that seem to exist across their respective industries.

We start the rest of the paper by exploring a selection of the most pertinent literature sources to outline the main concepts of the study and better explain its rationale. Next, we present the highlights of our earlier quantitative project that suggests the existence of cross-industrial differences in Internet dialog capacities. What follows is the methodological framework for the case-study research, the elaboration of findings from each of the four companies and a conclusion at the end of the article. 


\section{Internet Dialog in the Literature}

The right choices in designing corporate web pages can enhance customer engagement in dialog. However, the literature shows no consensus as to what these choices should be, as Garett et al. (2016) find in a comprehensive review of over a hundred published articles. They point out that "different disciplines and industries have different objectives in designing websites and thus should prioritize different website design elements" (p. 6). Some websites are designed to enhance brand loyalty and preference that support sales, while other focus on content accuracy and privacy. Therefore, Garret et al. conclude that there is no universal cross-industry model for the most engaging website. The notion that different industries have their own ways to engage customers in online dialog - which frequently reflects their varying communication objectives - appears in several other authors (e.g. Holland and Backer, 2001; Krishnamurthy, 2007).

One aspect of the Internet experience that scholars expect to foster dialog is interactivity, defined as "the extent to which the communicator and the audience respond to each other's communication need" (Wu and Chang, 2005, p. 238). However, the current study concentrates more on a narrowed-down version of this definition that arguably better applies to the Internet environment: the so-called machine interactivity is the extent to which users can participate in modifying the form and content of a mediated environment in real time (Hoffman and Novak, 1996). Its pivotal role is emphasized in the Interactive Dialog Model (IDM; Bolchini and Paolo, 2006, Bolchini et al., 2009) and its extension, the Rich IDM (Mainetti et al., 2012). IDM integrates theories of dialog with user interaction and experience to provide guidelines for effective web engineering, which should induce in users a feeling of uninterrupted flow and fluid transition between interactional instances. Here, a high level of interactivity enables the user to freely manage information choice and flow. The authors of this model illustrate it with three case studies of companies that serve different consumer markets. They conclude that each industry requires a unique approach to interactivity-enabled dialog.

According to Brown, social media hinge on "communication interactions which create, share and exchange information and ideas in virtual communities and networks" (2017, p. 3). Brown distinguishes social media from social networking as directed toward "getting people to collaborate, share experiences and get advice that may improve their lives or help them make better decisions" (p.3). Social networking involves interactions in online communities to share experiences and exchange information helpful in solving everyday problems and decision making. In contrast, social media provide technological means enabling these communities to function and social networking to occur. Social media are Internet-based digital technologies that facilitate the creation 
and exchange of user-generated content (Valentini and Kruckeberg, 2012). They are diversified platforms that encompass a variety of instruments such as "word-of-mouth forums including blogs, company-sponsored discussion boards and chat rooms, consumer-to-consumer email, consumer product or service rating websites and forums, Internet discussion boards and forums, moblogs (sites containing digital audio, images, movies, or photographs), and social networking websites" (Mangold and Faulds, 2009, p. 358).

In our project, we investigate corporate communication activities to trace dialogic conversations that support social networking and engage website visitors to cooperate and form communities.

According to Romenti et al. (2016), dialogic conversations are "the exchanges of micro-communicative processes built around dialogic communications" (p.329). Having reached a required level, dialogic communications enable dialog to occur. In this approach, not every conversation has the potential to establish a dialog, but each manifests an interaction. Although most consider social media presence an inexpensive instrument of communication, effective dialogic conversations require managers to implement a strategic process that may be time - and resource-intensive.

According to Mangold and Faulds (2009), "the content, timing, and frequency of the social media-based conversations occurring between consumers are outside managers' direct control” (p. 357). In their view, managers should find ways to influence consumer interactions so that they are consistent with the organization's mission and its objectives. Accordingly, this paper aims to investigate manager attitudes and efforts to establish direct digital communications with consumers through web pages and social media with a focus on their dialogic qualities.

\section{Evidence on Cross-Industry Differences in Internet Dialog in Poland}

As mentioned above, past research suggests that the implementation of dialog varies across industries in terms of its forms, intensity, and outcomes. Our own earlier research also offers insights into cross-industrial differences in Internet-enabled dialog (Witek-Hajduk et al., 2017a, 2017b). Our previous work examines the websites of 402 Polish consumer brands owned by exporting firms. Initially, we anticipated that exporters intensely engage in Internet communication with international customers. However, the results of our study evidence the existence of systematic differences in how various types of brand owners use dialog with consumers. The study compared website attributes with Internet traffic metrics and financial outcomes of owner companies. 
To explore how the type of company and its market environment can affect dialog, we grouped all firms into four clusters:

- Food and beverage $(\mathrm{n}=125)$,

- Cosmetics, pharmaceuticals, household essentials, and other fast-moving goods $(\mathrm{n}=62)$,

- Fashion and personal image products, such as clothing, shoes, accessories, and jewelry $(\mathrm{n}=68)$,

- Other durable goods, often technically complex, such as consumer electronics, video games, household appliances, bicycles, and yachts $(\mathrm{n}=147)$.

Over half of the firms had revenues of more than 100 million PLN (54.8\%) and employed more than 250 people (53.7\%). All investigated companies were exporters headquartered in Poland.

One limitation of the study was that - in the absence of employee interviews - the sole source of data about dialog were websites, which reflect the capacity for dialog rather than dialog itself. We used four composite variables as proxies for the scope and intensity of two-way communication with customers: (1) interactivity as the number of ways of interacting with the website, (2) the number of forms of contact for customers, (3) the number of website language versions, and (4) the number of social media profiles linked to the website. Table 1 shows the means of the four variables and ANOVA test results.

The ANOVA results show significant cross-industry differences in all four proxies. Interestingly, no single group of firms was better than the rest in all dialog capacities. Manufacturers of other durable products excelled at interactivity and the number of language versions. Food and beverage firms had better than average results in forms of contact with customers but were relatively weak in other variables. Fashion and personal image firms heavily relied on social media but offered the smallest number of forms of contact for customers, and they had the fewest language versions on average; interactivity was the worst quality of FMCG firms, that is, the first two groups.

Our statistical models regressing Internet traffic measures on website attributes yielded several noteworthy observations. Most interestingly, interactivity turned out to not correlate with either the time spent by a visitor or the average number of pages displayed during a visit. We expected a positive link, but there was none. One possible explanation is an overall low level of interactivity of the investigated websites, as $79 \%$ of them offered no interaction possibilities and only $3 \%$ gave customers at least three 
ways to change or adjust website contents. In fact, the only dialog capacity of the four considered variables that was a meaningful predictor of the time spent on a web page and the number of pages browsed during one visit was the number of social networks linked to a web page. This positive association suggests that social networks may be the dominant factor in engaging consumers. Moreover, firms that used more social networks may have a better understanding of how to design and operate their web service to make it more attractive to consumers.

Table 1. Comparison of industry groups on four dialog capacities with ANOVA tests

\begin{tabular}{|c|c|c|c|c|}
\hline \multirow[b]{2}{*}{$\begin{array}{l}\text { Industry } \\
\text { groups }\end{array}$} & \multicolumn{4}{|c|}{ Proxy variables for dialog capacity } \\
\hline & $\begin{array}{c}\text { Interactivity } \\
\text { of the website } \\
(F=2.690 \\
p=0.046)\end{array}$ & $\begin{array}{c}\text { Number of forms } \\
\text { of contact } \\
\text { for customers } \\
\text { on the website } \\
(F=5.609 \\
p=0.001)\end{array}$ & $\begin{array}{c}\text { Number } \\
\text { of language } \\
\text { versions } \\
\text { of the website } \\
(\mathrm{F}=9.238 \\
\mathrm{p}<\mathbf{0 . 0 0 1 )}\end{array}$ & $\begin{array}{c}\text { Number } \\
\text { of social media } \\
\text { profiles linked } \\
\text { to the website } \\
(\mathrm{F}=6.554 ; \\
\mathrm{p}<0.001)\end{array}$ \\
\hline Food and beverage & 0.264 & 1.712 & 1.216 & 1.176 \\
\hline $\begin{array}{l}\text { Cosmetics, } \\
\text { pharmaceuticals } \\
\text { household essentials } \\
\text { and other FMCGs }\end{array}$ & 0.238 & 1.810 & 1.857 & 1.254 \\
\hline $\begin{array}{l}\text { Fashion } \\
\text { and other personal } \\
\text { image products }\end{array}$ & 0.485 & 1.191 & 1.132 & 1.868 \\
\hline 0ther durable goods & 0.503 & 1.741 & 1.966 & 1.340 \\
\hline Whole sample & 0.385 & 1.650 & 1.576 & 1.365 \\
\hline
\end{tabular}

Source: own elaboration.

These findings seem to substantiate the claim that forms, magnitude, and outcomes of dialog depend on the type of offerings and market environment. However, the underlying reasons for these differences are not entirely clear, which validates further in-depth investigation.

\section{Conceptual Framework and Research Method}

The industry differences suggested by the other conceptual articles and our empirical research to date were the main reason for a follow-up project that we report in this paper. 
In this study, we employed the multiple case-study method and encompassed four companies; one from each industrial group listed in Table 1. We chiefly selected the firms based on the availability and goodwill of informers to fully disclose the requested information. As explained by Robert Yin (2003, p. 48-49), cases should be selected on purpose and not randomly, so as to make sure that they capture the diversity of the investigated phenomenon and allow researchers to discover recurring patterns through literal and theoretical replications. Moreover, what is an important criterion is availability, which means that cases need to provide a full scope of required data to be collected through interviews, observation, and document analysis.

For a short description of the firms in the current research, see the Table 2. We opted to use place-holder names as not all participants agreed to disclose their true names.

Table 2. Firms in the current research

\begin{tabular}{|c|c|c|c|c|c|}
\hline $\begin{array}{l}\text { Code } \\
\text { name }\end{array}$ & Key products & Employment & $\begin{array}{l}\text { Export share } \\
\text { in total sales }\end{array}$ & $\begin{array}{c}\text { Number } \\
\text { of foreign } \\
\text { export markets }\end{array}$ & Key foreign markets \\
\hline Firm A & $\begin{array}{l}\text { Fashion } \\
\text { products: } \\
\text { footwear, } \\
\text { handbags, } \\
\text { accessories }\end{array}$ & $\begin{array}{l}6500 \text { in Poland } \\
5500 \text { abroad }\end{array}$ & Approx. 30\% & 16 & $\begin{array}{l}\text { Central and Eastern } \\
\text { Europe }\end{array}$ \\
\hline Firm B & $\begin{array}{l}\text { Cosmetics: } \\
\text { nail polish, } \\
\text { eyeshadows, } \\
\text { other } \\
\text { make-up } \\
\text { products }\end{array}$ & $\begin{array}{l}800 \text { in Poland } \\
1100 \text { abroad }\end{array}$ & Approx. 70\% & 70 & $\begin{array}{l}\text { Middle East (United Arab } \\
\text { Emirates, Kuwait, Bahrain, } \\
\text { Saudi Arabia, Oman, } \\
\text { Qatar), Australia, Ireland, } \\
\text { Russia }\end{array}$ \\
\hline Firm C & Luxury yachts & 450 in Poland & $98 \%$ & 25 & $\begin{array}{l}\text { Western Europe (Belgium, } \\
\text { Switzerland), USA, Middle } \\
\text { East, Dubai, Emirates, } \\
\text { Asia, Eastern Europe }\end{array}$ \\
\hline Firm D & $\begin{array}{l}\text { Confectionery: } \\
\text { cookies, } \\
\text { wafers }\end{array}$ & 450 in Poland & Approx. 50\% & 64 & $\begin{array}{l}\text { Central Europe, Great } \\
\text { Britain, South Korea }\end{array}$ \\
\hline
\end{tabular}

Source: own elaboration.

The sources of information included published articles on the companies, analyses of their websites and social media profiles, and in-depth interviews with key informers: managers responsible for consumer relationships supported by crucial non-managerial 
employees with hands-on experience in interacting with customers through managing websites and social media. We transcribed all interviews and subjected to content analysis in search of patterns that concern the central concepts of the study.

The 3-M model (Gallagher and Ransbotham, 2010) was used as the theoretical framework for analyzing engagement in dialogue and classifying manifestations of Internet communication into three groups: company to customers (Megaphone), customers to company (Magnet), and between customers (Monitor).

In the first group, companies use the Internet as a mass communication channel, like a Megaphone through which they convey brand image information, explain the benefits of their products, and advertise promotional programs. The content of these messages is not personalized as they address many unspecified groups of recipients.

The second group of tools is called Magnet, because their task is to attract customers and prompt them to talk with the company. For customers to share opinions and ideas, the company must create the right conditions through well-designed and - maintained websites and social media profiles. Furthermore, the company must motivate customers through appropriate initiatives like contests, loyalty programs, and reward promises. The information stream from customers may inspire product innovation or enhance other instruments of marketing strategy. Positive feedback can also be instrumental in promotional purposes, as it usually impacts customers with more strength than information generated by the company.

While skillful communication management can turn customer-to-customer interactions into good relationships with the company, customers will always exchange information among themselves, especially in such a favorable environment as social networks. Since this situation is inevitable, companies should make every effort to understand the content of their customers' conversations. This can be done by means of appropriate monitoring tools for popular social networks or by creating controlled platforms for clients like a discussion forum. Effective monitoring allows companies to observe signals that suggest problems and threats, but also opportunities.

The three types of Internet tools complement each other and, therefore, are the most effective when used jointly by creating a coherent system of two-way communication.

This paper categorizes web tools according to their dominant purpose, as described by informants. Thus, if a tool primarily disseminates information about the company and its brands to a wide group of recipients - both customers and distributors - we 
included it in the Megaphone group. If the main use of a tool was to trigger customer reactions, like postings or e-mails, we placed it in the Magnet category. Whereas we situated activities and tools focused on generating and measuring customer interactions in the Monitor group.

\section{Findings}

For the types of Internet tools facilitating dialog and a summary of the results obtained in the four companies, see the Table 3.

Table 3. The use of Internet tools for dialog with customers in investigated companies

Tool description

\section{Tool effects}

\section{Firm A}

\section{MEGAPHONE:}

1) A website in 17 language versions dedicated to promoting new collections and supporting sales through traditional retail channels. As of the time of this research, it offered no e-commerce, but this functionality was to be added soon.

2) Visual content elements are standardized, though developed with inputs from managers operating in each of the 17 countries.

3) Most of the tasks with website upgrading and updating are outsourced.

\section{MAGNET:}

1) Shoe testing and contests announced in social media engage customers in the firm's activities. Customers are encouraged to send new shoe design proposals and shoe inspired photos. Valentine's Day contest had customer submit photos with a partner and explain why they are a good match.

2) Facebook, Instagram, and YouTube are social networks used to communicate with customers. In addition to the general account, every store in every country has its own profile which gathers posts from local customers. Facebook profile is used to inform about new collections and special offers. Customer
1) Google Analytics is used to measure traffic on the website, evaluate the effects of promotional campaigns, and link it to sales. However, no connection was found between sales and Internet traffic.

2) According to the interviewees, cooperation with local managers resulted in a unified brand image while accounting for local specificity.

3) Website design is attractive and professional.

1) Response from customers is positive with many of them partaking in contests and sharing their thoughts on new shoe ideas. However, these insights do not translate into new product designs, except for new color variants.

2) Social media seem to contribute to promoting positive opinions that, according to the managers, support sales, and help to avoid and resolve conflicts with customers. Complaints from customers on Facebook, though usually positively resolved, are not followed up to ensure keeping the customer. 
response is vivid, with impressions of shoes and bags, questions about product availability, and some complaints.

3) The Facebook profile is serviced by an outside firm whose employees handle most of the responses.

MONITOR:

1) Facebook posts by customers are visible to everyone but are rarely forwarded to other Facebook users to start a multilevel dialog. Most conversation threads end with a response from the firm (the outsourced company).
Facebook profiles (516 thousand followers) are much more customized to local markets than the websites, which may explain their greater popularity with consumers.

3) The lack of direct contact with customers may be the reason why customer ideas are rarely transformed into innovations.

1) The posts are reviewed but not systematically analyzed. It is difficult to identify their impact on decisions regarding brands owned by the company.

\section{Firm B}

\section{MEGAPHONE:}

1) A website in English is used as a global business card. It connects the visitors with shops across the world pointing to their web and social media pages. These media are localized by franchising partners or the company's employees who service its seven major markets. The website offers a directory of products for advertising purposes.

2) The websites of all shops have contact forms and customers can comment on each product presented in the catalog. All comments are displayed, including negative ones, except for those with expletives.

3) All physical shops in foreign countries engage in e-commerce. In Poland, Internet sales are centralized, so the e-shop serves all customers. The website supports sales in other markets by linking customers to the nearest e-shop.

MAGNET:

1) Facebook, Instagram, YouTube, and Snapchat are the major social networking portals used to communicate with customers, but their popularity varies across markets. For example, in the USA, Instagram is more important than Facebook. International customers are serviced by local retailers through their own profiles, but visual content is provided by the headquarters. In addition, every shop offers a blog.
1) The firm constantly keeps track of the traffic on the website to learn more about its visitors. Employees regularly browse competitors' websites to look for inspiration in layout and functionality.

2) Comments of visitors are regularly analyzed to create models of trends in the make-up market, which are a factor in strategy development. Outsourcing Internet operations to foreign retail partners enables tapping into local knowledge on customers and language. Despite having certain freedom on the Internet, franchising partners are monitored by the headquarters to keep brand positioning under control.

3) Retailers are a key source of local market data. Feedback from retailers is collected and analyzed weekly to serve as an input in production and sales planning.

1) Social media profiles are very popular with Internet users partly because they are tailored to local preferences and sensitivities.

Ensuring that profiles are properly localized in domestic languages is the duty of national retailing partners. To keep the conversation with customers consistent with the corporate image, the activities are monitored by the headquarters. 
2) In many countries, the Facebook profile is the most important one. It attracts customers by offering make-up tutorials, invitations to events, and competitions. Dialog with customers mostly concerns product features. Many posts show appreciation for the brand, but some entries are critical of service in stores. Answers to comments are posted very quickly, sometimes within a few minutes.

3) Customers are drawn to the website and Facebook profile by posts about attractive international events with the participation of the brand or its ambassadors, e.g., top tennis player Agnieszka Radwańska or actress and singer Jennifer Lopez. This way, the company addresses its promotional and public relations objectives are addressed.

4) Social media are an outlet for publishing pictures, video clips, leaflets and interacting with customers by responding to comments. About 40 people in the headquarters are engaged in Internet operations with the focus on social media. They design content, interact with profile visitors, and support retailing partners.

MONITOR:

1) Comments posted on the Facebook profile in each country are visible to all visitors to the profile. There are cases where a thread is continued by other people. However, the instances of creating consumer groups that intensively engage in dialog about the company or its products are rare.
2) The comments by customers inspire the firm by suggesting new shades, colors, and functionalities of stores. Visitor entries allow the firm to draw conclusions about satisfaction with products, the reception of new strategies, and nascent or disappearing trends. Dialog with customers has led directly to the introduction of new colors and shades. Other product innovations resulted from the analysis of unsatisfied needs voiced by large numbers of customers. For example, their remarks that varnished nails require careful maintenance have led to introducing nail care and protection products. The Facebook profile has over 500 thousand followers.

3) Social media give customers the feeling of participating in famous fashion shows. Invitations to events, competitions, regular coverage of fashion shows, and engaging celebrities to support brand image increase the interest in online shopping and social media profiles along with physical stores.

4) Updates are daily, which keeps visitors interested. Connecting with customers is an everyday task of many employees at the headquarters and on other national markets. They can respond to customers immediately and suggest relevant strategic and operational adjustments.

1) Customer posts are analyzed on a weekly basis and - if they require action - the matter is referred to the appropriate department (R\&D, Sales, Marketing) which makes decisions on the same day. Simple issues are resolved immediately. The conversations between clients are recorded and considered by the company, especially when it decides about its product range.

\section{Firm C}

\section{MEGAPHONE:}

1) The website in four languages is an important communication channel due to a large geographical dispersion of customers. It provides sales support by offering a detailed
1) The website allows the firm to be closer to customers, make them interested in the firm's products and possibly create the need to own a yacht. 
catalog of yachts to help affluent customers make a purchase decision.

2) Interactive advertising is meant to promote the brand and increase traffic on Firm C's website.

3) The website is managed and positioned by the company's employees (graphic designers and programmers).

4) The firm uses banners on portals and websites visited by enthusiasts of yachts and motor boats, such as the Boat International Magazine.

\section{MAGNET:}

1) The company uses social media, considering them to be more effective than advertising. According to the interviewee, Instagram is underestimated, and its unique advantage is availability in China, where Facebook is blocked. Instagram is popular with young people in Asian countries who have a great influence on their parents' decisions to buy luxury products such as yachts. In addition to Facebook and Instagram, firm $\mathrm{C}$ uses local social media such as Wee Chat in China.

2) Social media contents are often updated by the company's team.

3) About twice a month, a newsletter is sent to customers to inform about new products and encourage them to visit the company's stand at trade fairs.

4) Often, the details of an order are determined online. Conversations happen via e-mail, instant messaging, and Skype.
2) The website positively influences the firm's brand image perception.

3) The interviewee was very satisfied with the website positioning results; she claimed that the positioning was very good by all standards; e.g., entering specific keywords displayed the firm's website in the first place.

4) These advertisements seem to reach potential customers and increase brand visibility.

1) The profile on Facebook is followed by 18 thousand people, which is a significant number, considering that the company sells less than 20 yachts a year.

2) The problem is the weak responsiveness to posts from profile fans; on average a post prompts only a few dozen likes and comments, mostly from recurring users. Therefore, it seems that the posted materials may not have sufficient impact.

3) The newsletter is a way to maintain long-term relationships with customers. It also acts as a research tool for the assessment of interest in the company and its offer (based on click-throughs). Employees keep track of customers' reaction to the newsletter (click-through rate). A regular lack of response may result in an employee attempting to contact the customer directly.

4) Setting the terms of a contract and the specification of a yacht through the Internet seems effective and efficient as most clients come from places significantly distant from Gdańsk, where the company is located. 


\section{MONITOR:}

1) Employees constantly monitor and analyze entries on the company's profiles in social media. People who like the posts and publish comments are classified as fans, potential customers, or influencers; e.g., captains or children of wealthy parents.

2) The firm also monitors the Internet outside the areas of its direct influence, with emphasis placed on preventing unauthorized use of its brand. Conversations between sailing and yachting enthusiasts are also explored on websites dedicated to yachting.

3) Active support for brands by opinion leaders is considered much more effective in this industry than traditional advertising. Often, it is also cheaper. One of the opinion leaders who took an interest in the firm (nicknamed the Yacht Guy) has an Instagram profile followed by more than 800 thousand fans. He had the opportunity to visit the company's stand at a trade fair.
1) The small number of comments on the company's social profiles simplify the identification of the most interesting visitors and allow the firm to contact them directly. However, interactions between potential and actual customers rarely turn into a dialog.

2) The purpose of monitoring is to ensure that the company does not lose its good image due to illegitimate brand use. Analysis of the context in which the brand appears on discussion forums allows the firm to finetune its brand communication strategy.

3) One positive post about Firm $C$ from the Yacht Guy resulted in 6 thousand likes from his Instagram followers. It was free of charge and significantly increased the recognition of the brand. In the future, Firm C intends to use this solution more frequently, also by paid contracts.

\section{MEGAPHONE:}

1) The company uses its website to inform consumers about the distinctive features of its products, such as the use of natural ingredients and the absence of trans fats in recipes.

2) The responsibility for websites for foreign customers rests entirely on the company's partners. The forms of tools vary as there is no content standardization or control by the company.
1) Most consumers buy cookies and confectionery with the minimum of psychological and intellectual involvement, hence the ingredients of the products are often of little interest to them. Sometimes they even prefer not to know the nutritional content of products.

2) The effects are difficult to assess due to the lack of reliable data. The Marketing Director argues that his company does not feel comfortable running websites for local markets on its own due to the significant differences in consumer behavior (e.g. in South Korea and Arab countries). Local partners are expected to be much more aware of these issues.

1) The company manager is satisfied with the results of the competitions, though has no specific evidence for their effectiveness. Nevertheless, he believes that a direct competitor makes better use of this form of communication, which results in customer created recipes showcased on the competitor's 
products. The aim of the contests is to increase brand awareness through interaction with consumers.

2) A series of several-minute-long clips on YouTube feature a participant of the Master Chef TV program, who acts as an ambassador of the brand, preparing desserts with the use of the company's products.

3) The company's Facebook profile is run by a subcontractor, although the company supplies the graphic materials. The profile is regularly updated (several times a month) with product photos and other entries like Christmas wishes or short reports from fairs around the world.

MONITOR:

1) The company does not conduct any organized monitoring of conversations among customers about its brands and products. The Facebook and YouTube profiles focus more on getting consumers to communicate with the company than stimulating consumer conversations. website. Still, the company will not copy its rival's ideas for fear of adverse market reaction.

2) The films are relatively popular; some clips with the brand's ambassador on his Facebook profile have been watched more than 100 thousand times. However, the videos that show the company's sweets do not attract as many viewers (in most cases only several thousands). The brand name in the videos is poorly noticeable because the main role is played not by the products, but by the brand's ambassador's persona. The number of comments under the videos that reference the featured products is minimal.

3) The profile has a small following (less than 8000 ) and does not evoke strong reactions; on average, about a dozen likes per post. The commitment of clients is weak: most posts have no comments or only a few.

1) The lack of knowledge about how customers perceive the company's products in their conversations with each other may result from the lack of such online content, as Firm D's brands may be little known. On the other hand, activities in social media were not very effective as they did not prompt consumers to discuss the company's products.

Source: own elaboration.

It is clear, that the nature and effects of online dialog are diversified across the four cases. However, some recurring themes suggest the existence of shared patterns. Below, we offer a closer and more nuanced look at each company, including quotes from key informants.

\section{Firm A}

The company has been a reseller of footwear for various brands for over ten years. Until recently, it operated only physical stores in almost 20 European countries. The purchase of a majority stake in a large international online footwear store created new 
e-commerce opportunities. The firm plans setting up an online store under its own brand in the near future.

The company has a website in Polish and the languages of the countries in which it operates. It presents shoes in an inspiring and attractive way. Visitors are encouraged to join a loyalty program, which results in receiving personalized promotional offers. They can also fill out a form to share their feedback with the firm and other clients. The company admits that it moderates entries on the website and does not publish all comments. It is difficult to say to what extent entries are an inspiration for the company. With an exception of the variant addressed to women, the website is largely standardized, looking very much the same regardless of the language version. The management is aware of the shortcomings and plans to offer more diversity: "We are now working on a new website, also to deliver greater customization. We will have to reconcile two things on the site. The first is the nascent e-commerce to sell our products, while the second is image building and inspiring customers.... I don't know yet what it will look like.... This will probably involve an adaptation of the website to the specifics of the markets."

The site informs about the company's presence on social networks, including Facebook, Instagram, and YouTube. But not all social networks are equally important and used for the same purpose. Instagram is a tool for creating brand image - in no small part through publishing photos - Facebook is a platform of dialogue with customers, while other platforms are not used in a planned and systematic way. Informers indicate that responses to customer comments on Facebook are immediate. However, the responses do not always offer solutions to customer problems, but only acknowledgments that they were heard. Solutions to problems require more time as they often involve consultations with other departments.

Many entries on the website and social network profiles are provided by women who "wish to share their love for shoes and handbags" and express positive opinions about the firm's products. Employees responsible for online communication with customers have to respond to posts in such a way as to transform them into purchases.

Negative feedback from customers mostly regards refusals to accept returns of defective products by the physical store where the shoes were bought. As a rule, the approach is to "extinguish the fire," with a suggestion to appeal from the first decisions, which often results in an effective return of the product.

Despite management's and employees' declarations about the importance of the Internet and substantial funding allocated to this sphere of contact -including hiring external 
agencies to run profiles and expenditures on Internet terminals in physical stores - it seems that the company did not fully benefit from the potential of online communication. Only two people at the headquarters are responsible for Internet activities and one person in each of the serviced foreign markets. The influence of dialog with clients on business decisions is also limited. When asked about the activity of clients on Facebook, the company's representative explains: "Yes, they are engaged, of course. People get involved because shoes are also emotions to them." However, ongoing conversations with clients on Facebook do not translate into major modifications of the firm's assortment. When asked about the prospects of fitting offerings to the preferences of customers voiced online, the answer was: "For this and the next season, we will still be stuck with the old offer." The company learns fashion trends and seasonal changes from cooperating research agencies, whereas the only input from customers that reflects on the current assortment are color preferences.

Although the company was active online for over a dozen years, it is aware of many tasks and challenges that are still ahead to enhance its consumer online communication: "Previously, the obstacle was the cost of access to technology and the cost of connecting and using the Internet. Now, these costs are lower, and the smaller they get, the more widespread this access is; so it was only natural that our company decided to participate in these activities.... But we still have a lot to do. And these technologies are developing very quickly." To respond adequately to such challenges, the firm takes a proactive stance: "We look for the best talent to bolster our e-commerce and marketing operations; for example, we recently employed the former director of marketing and e-commerce for Europe at Sephora and the head of marketing at Reebok."

\section{Firm B}

Company B strongly focuses on the Internet, which is confirmed by its president and lower-level employees of the most pertinent departments. The company constantly improves its website, which serves as a showcase of its visually attractive achievements and broad offer.

Colorful cosmetics are a graceful object of appealing pictures, so the site draws attention. It is in English, on an international domain, and targeted to those who want to know the brand, its products, the way of purchasing, or consider cooperating with the company. The website has a catalog of products with links to online shops and a map of all physical shops. To make the site more attractive, it contains presentations of worldwide events with the participation of the brand. 
The international website enables visitors to give feedback to the employees of the company. This is how the dialog on the website is described by the PR staff: "There is a contact form on the website. We also have product pages, where one may comment under each product. Each user can make a comment under each product and we publish all of them, not only the positive ones. We try to be reliable." Comments are analyzed and promptly followed-up by the employees who seek to address the issues.

The head office maintains a shop in Poland, while its subsidiaries run shops in seven large foreign markets. Many physical and Internet shops are operated by franchisees, who follow the rules introduced by the head office but mindful of the local customs, trends, and other market conditions.

Like the websites, some aspects of social networks are centralized, while other are subject to differentiation required by local markets. Each physical store is present in social networks and maintains its own blog. Franchisees who run the stores are responsible for their Facebook profile and local social media profiles. The rules of interacting with customers are strictly defined for the whole network, although the company taps into the creativity and knowledge of local partners and permits diversity without compromising the overall image of the brand. Marketing and PR departments at the headquarters monitor and analyze activities in social media in terms of coverage, quality, and speed of response, as well as the compliance with corporate policies. They say: "Every form of contact works.... People post comments and we have quite a lot of them. The message gets across, so we know that social media are used.... This shows that all channels function well."

Dialog with customers develops continuously. Facebook and Instagram posts come in daily from countries where the company operates on its own. Franchisees who manage their own social media profiles prepare weekly reports on their activities. The company has procedures to effectively process and respond to all this information and follows them in both operational work and strategic decision-making. Employees of the departments involved in Internet activities comment on this: "Social media fulfill this and many other functions. Obviously, we are not doing that to have a pleasant chit-chat. There are many valuable things that come out of our contacts with clients through social media. For one, it's our image that we need to care about, and that calls for constant monitoring and prompt reaction time. Also, it happens that customer feedback carries interesting ideas and is a source of inspiration." Some of the comments are motivating for the employees: "Here on the wall hangs one of the letters of appreciation - it is so emotional. And whenever the mood is worse, you can look at it and feel better right away." 
The company makes a point to react immediately to customers' comments: "Meetings are held every week in the marketing, sales, R\&D, and, of course, the management board. This is when reactions to tougher issues can be determined. Outside the meetings, there is constant communication. If a more routine customer message is received on a subject related to an online shop, a purchase, a complaint, or a request for a product, it gets forwarded to the relevant department and processed on the same day."

This is how marketing department employees comment on the bilateral nature of communication with stakeholders: "We have effective communication: information flows in both directions. We can learn and get our message across. This applies to partners, potential partners, and customers."

It seems that the dialog between customers is not very intense, although - from a technical point of view - the company provides suitable tools, which sometimes foster longer conversations. However, there are no special incentives for participants to engage in debates.

To sum up, the company appears to demonstrate an organizational culture that supports the use of the Internet and emphasizes dialog with stakeholders, especially customers. As the Marketing Director says: "Customer information influences what we plan and do. Customers are involved in the planning process because they shape it." He adds: "The only way to be flexible is to adapt to customers, to talk to them."

\section{Firm C}

Construction of luxury yachts undoubtedly is a very specialized field that serves relatively few very affluent customers scattered all over the world. In a typical year, Firm C sells 10-14 vessels to foreign customers, which accounts for over $90 \%$ of its whole production.

This business model presents the company with quite different challenges from those in the mass market. Each yacht is manufactured to order, based on several standard components - like a set of different hull versions - but still according to a customer's instructions, especially in terms of finish and aesthetics. Therefore, intensive dialog with customers is essential for the proper identification and satisfaction of their needs. The small number of potential and current clients makes Firm C's approach to each customer very individual. Nevertheless, interviewed employees stress the importance of mass communication channels, such as a public website and the Facebook profile. 
A mechanism similar to that observed in other luxury markets seems to be at play here, whereby mass communication - such as advertising expensive cars in popular TV shows - serves not so much to attract customers as to strengthen the impression of brand exclusiveness, in line with the principle that if a brand is widely regarded as a high-status symbol among the general public, those few who can afford it may prefer it more strongly. Therefore, both the website and the Facebook profile are carefully designed with frequent updates that present captivating photos of yachts on offer, mark product modifications, or appearance on trade fairs. The interviewees stress that it is important to ensure the feeling of regularity of communication and strengthen the image of a company that offers unique products, continuously improved to meet the high expectations of customers.

More than 18 thousand followers of the Facebook profile seem to be a large number, considering the elitism of the market served. The average number of likes of individual posts at 40-60 and the minimal number of comments make a less positive impression. However, the wealthy target group members may be less inclined to interact with social profiles compared to the mass buyer.

Most feedback from clients concerns their preferences about the finishing of the yacht they are buying. The uniqueness of Firm C's industry is that each client has his or her own ideas, which the company must consider when working on each vessel. However, most of them concern interior design, furniture selection, and functional aspects, which rarely pose an engineering challenge or the kind of product innovation that could improve the future offer. Nevertheless, there are exceptions: "We made one vessel for a prince in Abu Dhabi, and it is the only catamaran in the world that has a folding mast. It's a very interesting story, because this customer ... frustrated with a bridge not far from his house, insisted on having a folding mast. Everyone said that it was impossible, but the president was adamant that it can be done. So, he called the producer of this film with Kevin Costner where there appeared such a motif with the assembly of a mast and the producer recommended good designers. After talking to them, we decided that such construction was feasible."

According to the company's representative, the biggest challenge in applying an open communication policy via the Internet is the protection of intellectual property rights, such as imitation from dishonest competitors of certain construction solutions or even entire yachts. It also happened that unauthorized parties pretended to be the owners of the brand. Most such problems occur in Asia, so Firm C's employees closely monitor its online presence on that continent. 
In general, Firm C's online communication policy aims to reduce brand anonymity and strengthen its perception as a symbol of prestige and luxury, which is likely to have a positive impact on sales performance.

The company does not directly measure sales effectiveness of its website and social media, but the interviewee strongly believes that their impact is high, because she does not "remember when was the last time that we had a client who found us through printed media."

\section{Firm D}

Firm D has a visually attractive website, thoroughly modified shortly before the interview. The content presents products and commercial information for consumers and distributors. There are promotional materials available in different languages that the company's distributors can download, print, and use at traditional points of sale. Although the website presents products in an encouraging way, there is not much useful content for consumers apart from the nutritional value and lists of ingredients. Firm D strives to initiate dialog with customers, but the communication to date has been primarily one-sided, from the company to customers. Customer feedback through online comments or e-mails has been negligible. The main obstacle to the effective use of the Internet as a medium for two-way communication with stakeholders seems to be the nature of the products: sweets are mostly impulse or routine purchases, which rarely involves customers emotionally and intellectually. Despite the current unfavorable situation, the Marketing Director sees some positive changes, even if still too weak to justify spending more on this type of communication: "There is a growing awareness of the benefits from reading labels. That is what we see and hear from all sides. And it's great because we have always regretted that we couldn't boast our avoidance of, say, trans-fats for several years already.... Nobody appreciated that. Nobody even understood what it was about. This awareness was very low even among frequent buyers.... Although we see a need for more communication, I think it still would be a waste of money today to do more."

As mentioned above, Firm D is open to ideas from consumers, though they received very few suggestions so far, and the ones it did receive were not feasible. This is how the Marketing Director describes information routinely received from customers: "There are different inquiries. Sometimes they are very trivial: where can you buy our products? One could say that it is a strange question. But it must also be answered. Some 
people want to know why some products don't taste the way they used to and, sometimes, they do not even ask about our products. But people have the right to write. The funniest thing was communication from prisoners who asked for samples of products because they wanted to test them.... There are also positive things, like when someone bought a product and they liked it very much. They thank us, send their greetings."

According to the interviewee, the main barrier for the development of dialog is the lack of a good concept for the website and Facebook profile. The experience of searching for a professional and creative subcontractor was also discouraging. It was difficult to find a firm who could offer a comprehensive service of Internet solutions in an original way, unlike the uninspiring commonly-used standards. In the opinion of the Marketing Director, large Internet service companies are not original, while the small ones lack the potential to meet their commitments on time. Although at the time of the interview Facebook profile managing and website positioning were contracted out to an external firm, the results were discouraging.

In conclusion, despite the positive attitude to the Internet in general and dialog with customers in particular, the prevailing sentiment in Firm D is that this is currently not very important for corporate performance, but "it is something to have, just like a business card, because without it the company would be perceived as strange, perhaps as less credible." On several occasions, the interviewee stressed that he did not have any "hard" data to confirm the impact of online dialog or its lack on the condition of the company. Due to the lack of resources, Firm D does not conduct marketing research by itself, not even brand awareness studies, and it considers the methods used by research agencies, especially the large ones, as suspicious.

\section{Conclusions}

The relationship between interactivity and dialog is less straightforward than we initially assumed. It seems that so-called machine-interactivity, which corresponds to the extent to which users can modify online content, is necessary for ensuring a high capacity for dialog. In this respect, all studied firms provide sufficient interactivity, particularly with their use of social networks.

However, this capacity does not always translate into high-intensity dialog, as it considerably varies across the cases, from Firm B at the top, through Firm A and Firm D, to Firm C. This shows that machine-interactivity is not the sufficient condition for 
a rich dialog with customers. The investigated firms show diversified speed and agility in how they react to consumer inputs, with Firm B excelling due to its very short response time and the ability to rapidly solve problems reported by consumers. In Firm A, even though responses are prompt, there sometimes appear delays in handling problematic situations. It resulted from Firm A's reliance on a third-party contractor to maintain social profiles, who had to consult the Firm's employees in non-routine situations. Firm D also involves a contractor for social media services which results in uninspiring experience for consumers and weak involvement on the part of the contractor. Firm $\mathrm{C}$ is the only one who does not operate in a mass market, so their presence in social networks does not require a large volume of posts and interactions with customers to be effective. However, the small number of Internet users who visited and posted on Firm C's profiles is treated with the attention that prospective buyers of luxury products could expect. These human contacts mediated by the Internet are another side of interactivity known as person interactivity (Hoffman and Novak, 1996), which complements machine interactivity. In our research, we observed that the best business results - although often based on anecdotal evidence rather than hard data - come from companies with the highest levels of person interactivity (Firms B and C), which corresponds to the highest levels of dialogic conversations. Therefore, it seems that - after achieving adequate levels of machine interactivity - firms should not rest on their laurels but exert additional effort to combine that with high levels of person interactivity. Admittedly, developing person interactivity on the Internet is expensive and difficult to implement and coordinate, so managers may be tempted to hire specialized contractors. However, our research suggests that the outsourcing of this task may prove counterproductive.

The nature of offered products and corresponding patterns of purchasing behavior seem to be important considerations in developing an online dialog with consumers. The low involvement in the purchasing process prevents consumers from exchanging information about products in a natural way, as happens in the case of articles that have a more technical nature (e.g. headphones, laptops or running shoes), are composed of complex flavors (e.g. wine or craft beer), or impact personal image (e.g. clothes, watches, or home décor). Manufacturers and distributors of the more engaging articles have an easier task of encouraging communication from customers (Magnet) and between them (Monitor), since many buyers spontaneously seek contact with the company and other buyers, for example, by creating discussion forums for users or consumers of said products. In the grocery business, one way to intensify the dialog could be to modify products toward functional foods (e.g. for people involved in sports or heavy intellectual work) or to meet the specific needs of narrowly defined target groups (e.g. young mothers, vegans, people caring for organic and natural food). 
In combination with insights from publicly available online sources - corporate websites, social media, industry portals, press articles, consumer blogs, and forums - our analyses of interview transcripts led to the following conclusions:

- All interviewees were convinced that dialog with customers strongly influences the competitive position of their firms. They also noted that the role of dialog would be growing in the coming years with the further rise of the Internet as a fully functional distribution channel for many products.

- It seems that despite financial and organizational commitment, no company has utilized fully the business potential of two-way communication with consumers.

- Dialog appears to have more business relevance for high involvement products - like clothing, cosmetics. or yachts - than for offerings typically bought with little commitment like sweets, which admittedly are simple products, often bought on impulse or by force of habit. Indeed, the investigated manufacturer of sweets has trouble finding an effective concept to attract and maintain the interest of customers in its Internet activities.

- Mass markets provide more opportunities to benefit from optimizing costs of communication both with final customers and business partners like distributors. In those markets, it is also easier to create the kind of social media presence that supports a thriving online community of customers, that would provide the company with inspiration and data for marketing research.

- Our case studies point to a greater importance of social networks for dialog than conventional web pages. According to interviewed informers, they are more interactive and easier to customize to accommodate special characteristics of local markets and customer segments.

- Unexpectedly, one of the barriers of adopting dialog with customers turned out to be the nature of cooperation with firms that provide services of website and social media development and maintenance. There emerged a pattern: the more outsourced tasks pertaining to web pages and social network profiles, the less effective the two-way communication with consumers. Firms that did more in-house had more interesting and engaging ideas, more up-to-date content, and better integration of Internet activities with real-life operations which - among other things - led to quicker response times to consumers' online posts.

- The major barrier in the further development of online dialog is poor measurability of Internet tools and activities. In every company, there were no reliable data linking what firms did on the Internet with their competitive positions in the market. Even so, the managers were convinced that such effects exist and 
are positive. This suggests that an important area of the future research could be methods of measurement of companies' presence on the Internet.

The overall managerial implication from our study summarizes the more specific guidelines above. That is, to successfully establish and maintain online dialog with consumers, companies require an adequate strategy, resources, and abilities. Only professionally managed development of attractive content can engage consumers in sharing market information and new ideas to support companies in their efforts to attain business goals. However, these strategies may differ across industries and particularly across foreign markets, where exporters sell their products.

\section{$\underline{\text { References }}$}

Bolchini, D. and Paolini, P. (2006). Interactive dialogue model: a design technique for multi-channel applications. IEEE Transactions on Multimedia, 8(3): 529-542,

https://doi.org/10.1109/TMM.2006.870733

Bolchini, D., Paollini, P. and Garzotto, F. (2009). Design requirements for communication-intensive interactive applications. In: K. Lyytinen, P. Loucopoulos, J. Mylopoulos, B. Robinson (eds.), Design Requirements Engineering: A Ten-Year Perspective, LN Series in Business Information Processing, Springer, Berlin, https://doi.org/10.1007/978-3-540-92966-6_23

Brown, M.A. (ed.) (2017). Social media performance evaluation and success measurements. Hershey, Pennsylvania, https://doi.org/10.4018/978-1-5225-1963-8

Gallagher, J. and Ransbotham, S. (2010). Social media and customer dialog management at Starbucks. MIS Quarterly Executive, 9(4): 197-212.

Garett, R., Chiu, J., Zhang, L. and Young, S.D. (2016). A Literature Review: Website Design and User Engagement, Online J. Communications Media Technology, 6(3): 1-14.

Grönroos, Ch. (2004). The relationship marketing process: communication, interaction, dialogue, value. Journal of Business \& Industrial Marketing, 19(2): 99-113, https://doi.org/10.1108/08858620410523981

Hoffman, D.L. and Novak, T.P. (1996). Marketing in hypermedia computer-mediated environments: conceptual foundations. Journal of Marketing, 60: 50-68, https://doi.org/10.2307/1251841

Mainetti, L., Paiano, R., Bolchini, D. and Pandurino, A. (2012). Dialogue-based modeling of rich Internet applications: The Rich-IDM approach. International Journal of Web Information Systems, 8(2): 157-180, https://doi.org/10.1108/17440081211241941

Mangold, W.G. and Faulds, D.J. (2009). Social media: The new hybrid element of the promotion mix. Business Horizons, 52(4): 357-365, https://doi.org/10.1016/j.bushor.2009.03.002

Mazur, J. and Zaborek, P. (2014). Validating Dart Model. International Journal of Management and Economics, 44(1): 106-125, https://doi.org/10.1515/ijme-2015-0012

Prahalad, C.K. and Ramaswamy, V. (2004). Co-creating unique value with customers, Strategy and Leadership, 32(3): 4-9, https://doi.org/10.1108/10878570410699249

Ranjan, K.R. and Read, S. (2016). Value co-creation: Concept and measurement. Journal of the Academy of Marketing Science, 44(3): 290-315, https://doi.org/10.1007/s11747-014-0397-2 
Romenti, S., Valentini, Ch., Murtarelli, G., Meggiorin, K. (2016). Measuring online dialogic conversations' quality: a scale development. Journal of Communication Management, 20(4): 328-346, https://doi.org/10.1108/JCOM-11-2015-0090

Vargo, S.L. and Lusch, R.F. (2004). Evolving to a new dominant logic for marketing, Journal of Marketing, 68(1): 1-17, https://doi.org/10.1509/jmkg.68.1.1.24036

Valentini, C. and Kruckeberg, D. (2012). New media versus social media: a conceptualization of their meaning, uses, and implications for public relations. In: S. Duhé (ed.), New Media and Public Relations, 2nd ed. New York: Peter Lang.

Witek-Hajduk, M.K., Zaborek, P., Mazur, J., Sznajder, A. and Targanski, B. (2017a). Cechy domen Internetowych polskich marek eksportowych a specyfika branży. Polityki Europejskie, Finanse i Marketing, 66(17): 189-199.

Witek-Hajduk, M.K., Zaborek, P., Mazur, J., Sznajder, A. and Targanski, B. (2017b). Związki między cechami domen Internetowych polskich marek a ich międzynarodową aktywnością w Internecie. Handel Wewnętrzny, 306(3): 189-199.

Wu, J.J. and Chang, Y.S. (2005). Towards understanding members' interactivity, trust, and flow in online travel community. Industrial Management \& Data Systems, 105(7): 937-954, https://doi.org/10.1108/02635570510616120

Yin, R. (2003). Case Study Research: Design and Methods. SAGE Publications, Inc., Thousand Oaks, California, USA. 